\title{
An Effect of the lon Phenotype in Escherichia coli as Indicated by the Growth of Amoebae of Dictyostelium discoideum
}

\author{
By P. A. FARNSWORTH AND R. JAMES \\ Department of Biology as Applied to Medicine, The Middlesex Hospital \\ Medical School, London, $W_{\mathrm{I}} P$ 6DB
}

(Received I6 June 1972 ; revised 6 July 1972)

\begin{abstract}
SUMMARY
A correlation has been observed in strains of Escherichia coli between the lon phenotype and the capacity to support the growth of Dictyostelium discoideum amoebae. $l^{\circ} n^{+}$strains, E. coli $\mathrm{B} / \mathrm{r}$ lon sul and $E$. coli $\mathrm{KI} 2 l{ }^{+} n^{+}$strain, when used as the food source, yielded approximately four times the number of amoebae as the lon- strains, E. coli $\mathrm{B}$ and $E$. coli $\mathrm{K}-\mathrm{I} 2 \mathrm{ABI} 899$.

The differences in yield may be caused by the release of an extracellular inhibitor of the growth of slime-mould amoebae by the lon strains. Interaction with this lon phenotype effect was observed with the DNA repair mutants $\operatorname{exr} A, \operatorname{rec} A$ or $u v r$. The effect of the inhibitor release on the yield of amoebae in E. coli B or E. coli $\mathrm{B}_{\mathrm{S}-2}$ was partially modified by conjugation into these strains of the sex factor $F^{\prime}$ lon ${ }^{+}$.

Reduced ability to support growth of slime-mould amoebae and high sensitivity to the antibacterial agent crystal violet appear to be properties specific to filamentous $l o n^{-}$strains. Two possible sites in the bacteria are suggested which may be involved in expression of the lon phenotype.
\end{abstract}

\section{INTRODUCTION}

The marked radiation sensitivity of Escherichia coli B and the E. coli $\mathrm{KI} 2$ strain ABI 899 results in part from the lon mutation which leads to filament formation after exposure to ultraviolet or ionizing radiation (Adler \& Hardigree, 1964; Howard-Flanders, Simpson \& Theriot, I969; Brown \& Gillies, 1972). The increased radiation resistance and lon $^{+}$ phenotype of $E$. coli $\mathrm{B} / \mathrm{r}$ is due to a mutation at the $s u l$ locus which suppresses the lon-induced filament formation after radiation treatment (Donch, Chung \& Greenberg, I969; Donch et al. 1971).

Attempts to correlate the lon phenotype with biochemical differences have been markedly unsuccessful. Biochemical analysis after irradiation has shown very similar metabolic changes in strains of either phenotype (Kantor \& Deering, 1968; Walker \& Smith, 1970), thus yielding little real knowledge of the reasons for filament formation in unsuppressed lon strains. In this paper we report on a novel approach to the study of the two genotypes which arose from observations made by one of us (P. A. F.) of differences in the pattern of growth of the cellular slime mould Dictyostelium discoideum.

During the vegetative growth phase of the life-cycle of Dictyostelium discoideum, with Escherichia coli, in two-membered culture on solid media, the amoebae ingest bacterial cells until, upon depletion of bacterial number, the amoebae enter the aggregative phase, forming, by a chemotactic mechanism, discrete groups of aggregated cells (Konijn, Barkley, 
Table I. Relevant markers and source of Escherichia coli strains used

\begin{tabular}{|c|c|c|}
\hline Strain & Genotype & Source \\
\hline Escherichia coli $\mathrm{B}$ & lon sult & Laboratory stocks \\
\hline E. coli в leu & lon $\mathrm{sul}^{+}$leu & R. James \\
\hline E. coli $\mathrm{B} / \mathrm{r}$ & lon sul & Laboratory stocks \\
\hline E. coli $\mathrm{B} / \mathrm{r}$ leu & lon sul leu & R. James \\
\hline E. coli $\mathrm{ABI}$ I 57 & $\operatorname{lon}^{+}$ & M. Green \\
\hline E. coli $\mathrm{ABI} 899$ & lon & M. Green \\
\hline E. coli $\mathbf{B}_{\mathrm{S}-2}$ & lon sul ${ }^{+}$exrA & M. Green \\
\hline E. coli $\mathrm{DBI} \mathrm{I}$ & lon sul exrA & M. Green \\
\hline E. coli PAM9942 & Ion $\operatorname{exr} A$ & M. Green \\
\hline E. coli PAM57I7 & $\operatorname{lon}^{+} \operatorname{exr} \mathrm{A}$ & M. Green \\
\hline E. coli $\mathrm{NG} 30$ & lon sul rec $A$ & M. Green \\
\hline E. coli См293 & $\operatorname{lon}^{+} \operatorname{exr} A \operatorname{rec} A$ & M. Green \\
\hline E. coli $\mathrm{B}_{8 \cdot 8}$ & lon sul uvr & M. Green \\
\hline E. coli $\mathrm{W} 3747$ & $\mathrm{~F}^{\prime} \operatorname{lon}^{+}$ & J. Lederberg \\
\hline E. coli в leu/F' lon $^{+}$ & lon sul ${ }^{+}$leu $/ \mathrm{F}^{\prime}$ lon $^{+}$ & R. James \\
\hline E. coli $\mathrm{B}_{8 \cdot 2} / \mathrm{F}^{\prime}$ lon $^{+}$ & lon $\mathrm{sul}^{+}$exr $\mathrm{A} / \mathrm{F}^{\prime}$ lon $^{+}$ & R. James \\
\hline
\end{tabular}

Chang \& Bonner, I969). We observed quantitative differences in the pattern of aggregation seen when different $E$. coli strains were used as the food source of the amoebae. Quantitation of such differences on the basis of the aerial density of aggregates under standard conditions proved difficult because of the step-function nature of the relationship between aggregate size and amoebae number (Hohl \& Raper, 1964). However, direct measurement of the number of amoebae yielded by a given initial number of $D$. discoideum spores and bacteria, after a fixed period of incubation, showed a direct correlation with the genotype of the bacterium used.

Experiments will be described which attempt to determine the nature of the effect of bacterial genotype on the yield of slime-mould amoebae, and the possible relevance of such results to the genotype determined radiation resistance will be discussed.

\section{METHODS}

Bacteria. The relevant genotype and source of the bacterial strains used is indicated in Table I. Cultures were maintained on slopes at $4{ }^{\circ} \mathrm{C}$ and grown overnight in Oxoid Nutrient broth when required. The bacterial concentrations of the exponentially growing cultures were estimated from their density as measured in an Eel nephelometer and dilutions made in nutrient broth.

Measurement of yield of amoebae. Plates of Sussman's SM agar (Sussman, I964) were inoculated with $2 \times 10^{6}$ spores and $5 \times 10^{7}$ bacteria, dried and incubated at $22^{\circ} \mathrm{C}$ for varying intervals before harvesting. For most experiments the incubation time chosen was $40 \mathrm{~h}$, the time at which the amoebae yield was reaching a maximum prior to aggregation. The amoebae were harvested from the plates by washing off in distilled water at $4^{\circ} \mathrm{C}$, and separated from bacterial cells by centrifugation at $\mathrm{I} 80 \mathrm{~g}$ for $4 \mathrm{~min}$. The pellet was resuspended in a known volume of cold water and the number of amoebae $/ \mathrm{ml}$ determined by haemocytometer counts (Phase $\times 500$ ).

F-duction of lon ${ }^{+}$into Escherichia coli strains $\mathrm{\text {в }}$ and $\mathrm{B}_{2-\mathrm{s}}$. The F-prime factor, Fi3, carries the chromosomal genes $\mathrm{lac}^{+}$and $\mathrm{lon}^{+}$(Hirota \& Sneath, I96I), thus F-duction of FI3 into Escherichia coli lon strains permits the study of dominance at the lon locus. 


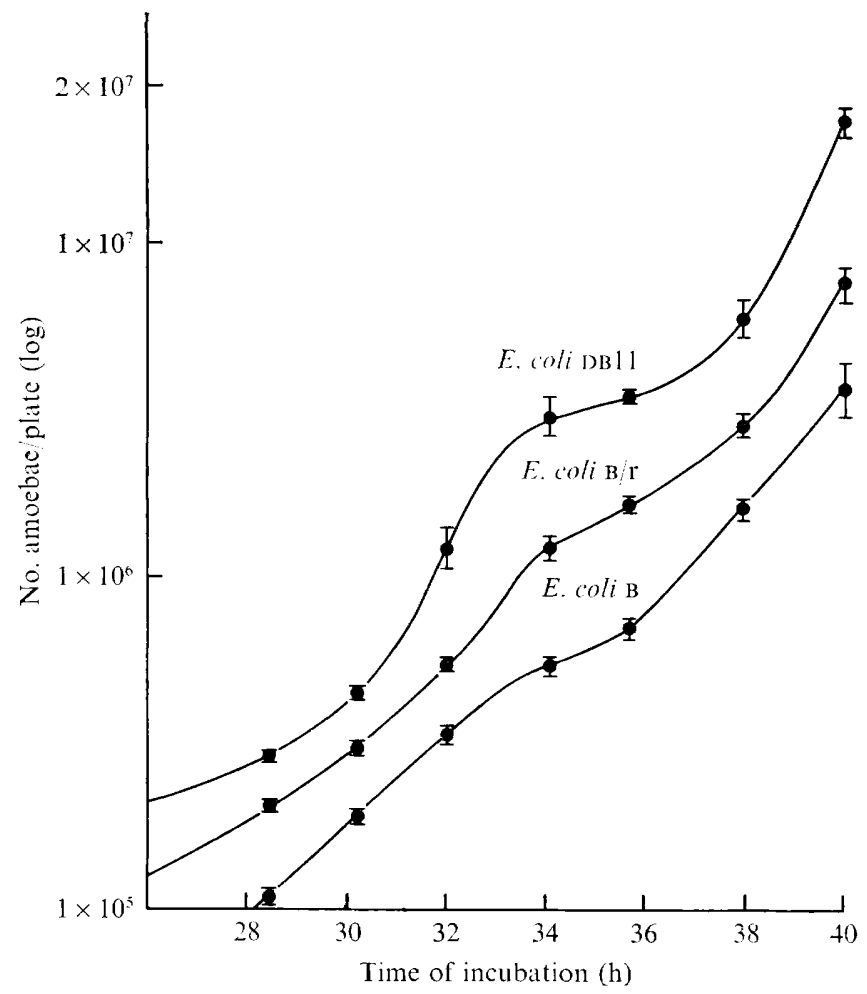

Fig. I. Kinetics of slime-mould amoebae growth on various Escherichia coli strains.

Streptomycin-resistant mutants of Escherichia coli strains в leu and $\mathrm{B}_{\mathrm{s}-2}$ were isolated after u.v. induction. Overnight log phase cultures of the mutants were mixed in the ratio of I : Io with the FI 3 donor, E. coli $\mathrm{W} 3747$ and incubated with shaking. Mating was terminated after Io min by vigorous shaking for $30 \mathrm{~s}$ and the cultures were then diluted $\mathrm{I}$ in Io into nutrient broth containing $200 \mu \mathrm{g}$ streptomycin/ml. After further incubation for $24 \mathrm{~h}$ at $37^{\circ} \mathrm{C}$ the required conjugants which had a requirement for leucine were selected by plating on streptomycin selective medium and exposing to u.v. (roo ergs $/ \mathrm{mm}^{2}$ ) after $2 \mathrm{~h}$ growth at $37^{\circ} \mathrm{C}$. The colonies obtained after overnight incubation were screened for the presence of $l n^{+}$by the technique of Walker \& Pardee (I967). Ultraviolet survival curves were performed on potential $l^{+}$/lon conjugants to check that the absence of u.v.-induced filament formation was associated with the expected sensitivity to u.v. radiation.

Because Escherichia coli $\mathrm{B}_{\mathrm{s}-2}$ does not filament after u.v. irradiation the above technique could not be used to demonstrate the transference of $\mathrm{F}^{\prime} l o n^{+}$into this strain. However, the presence of $\mathrm{F}^{\prime} l o n^{+}$in presumptive $E$. coli $\mathrm{B}_{\mathrm{s}-2} / \mathrm{F}^{\prime} l o n^{+}$conjugants was demonstrated by observing the increase in radiation resistance of u.v.-irradiated $E$. coli B when $\mathrm{F}^{\prime} \operatorname{lon}^{+}$was transferred from an $E$. coli $\mathrm{B}_{\mathrm{S}-2} / \mathrm{F}^{\prime} l_{\text {lon }}^{+}$donor.

Approximately $5 \times 10^{7}$ bacteria of Escherichia coli $\mathrm{B}$ were spread on to a plate of nutrient agar, several drops of the $E$. coli $\mathrm{B}_{\mathrm{S}-2}$ culture, assumed to contain $\mathrm{F}^{\prime} l o n^{+}$, were placed at intervals across the plate, allowed to dry, and incubated for $2 \mathrm{~h}$ at $37^{\circ} \mathrm{C}$. The plate was then exposed to u.v., $200 \mathrm{ergs} / \mathrm{mm}^{2}$, and incubated overnight. Sparse growth of colonies of $E$. coli $\mathrm{B}$ was observed over most of the plate, but where E. coli $\mathrm{B}_{\mathrm{S}-2} / \mathrm{F}^{\prime} l$ lon $^{+}$and $E$. coli $\mathrm{B}$ were mixed together confluent growth of colonies occurred. Control plates seeded only 


\section{Table 2. Variation of amoebae yield with host bacterium lon genotype}

The results are the average yields from six experiments, performed in duplicate, expressed as a percentage of the yield obtained with Escherichia coli $\mathrm{B} / \mathrm{r}$.

$\begin{array}{llc}\text { Strain } & \begin{array}{l}\text { Relevant } \\ \text { genotype }\end{array} & \begin{array}{c}\text { Amoebae } \\ \text { yield }(\%)\end{array} \\ \text { Escherichia coli } \text { B } & \text { lon } \text { sul }^{+} & 25 \pm 5 \\ \text { E. coli } \text { B } / \mathrm{r} & \text { lon } \text { sul } & \text { I00 } \\ \text { E. coli } \text { ABI } 899 & \text { lon } & 36 \pm 5 \\ \text { E. coli } \text { ABII57 } & \text { lon }^{+} & \text {I I } 6 \pm 6\end{array}$

Table 3. Amoebae yields in the presence of homologous and heterologous supernatants

Amoebae yields were determined as in Table 2 and expressed as a percentage of the yield for Escherichia coli $\mathrm{B} / \mathrm{r}$. The bacteria from overnight cultures of each strain (10 $\mathrm{cells} / \mathrm{ml}$ ) were separated by filtration $\left(0.22 \mu\right.$ Millipores) and $5 \times 10^{7}$ cells in $0.5 \mathrm{ml}$ of homologous or heterologous supernatants were incubated with $10^{6}$ spores at $22^{\circ} \mathrm{C}$ for $40 \mathrm{~h}$.

$\begin{array}{lcc}\text { Bacteria } & \begin{array}{c}\text { Culture } \\ \text { supernatants }\end{array} & \begin{array}{c}\text { Amoebae } \\ \text { yield (\%) }\end{array} \\ \text { B } & \text { B } & 20 \pm 4 \\ \text { B } / \mathrm{r} & \text { B } / \mathrm{r} & 100 \\ \text { B } & \text { B } / \mathrm{r} & 28 \pm 2 \\ \text { B } / \mathrm{r} & \text { B } & 58 \pm 6\end{array}$

with drops of the suspected $E$. coli $\mathrm{B}_{\mathrm{s}-2} / \mathrm{F}^{\prime} l o n^{+}$, and exposed to the same dose of u.v. yielded no colonies. Therefore the areas of confluent growth must have resulted from the growth of $E$. coli B into which $\mathrm{F}^{\prime} l o n^{+}$had been transferred. This indicated that this $\mathrm{F}^{\prime}$ factor must have been present in the presumptive $E$. coli $\mathrm{B}_{\mathrm{s}-2} / \mathrm{F}^{\prime} l o n^{+}$.

\section{RESULTS}

Variation of amoebae yield with lon phenotype of Escherichia coli. The rates of growth of amoebae of Dictyostelium discoideum incubated with three strains of Escherichia coli are shown in Fig. I. Too few amoebae were present at the beginning of the incubation period to allow counts to be made before the end of the first $24 \mathrm{~h}$ of growth. However, we have shown that the spore germination frequency, measured microscopically by determining the number of ungerminated spores per unit area of plate after $4 \mathrm{~h}$ of incubation, is the same for these three strains (P. A. Farnsworth, unpublished). Therefore the amoebae yield determined just prior to aggregation is a reflection of the growth rate of the amoebae over the experimental period.

The amoebae counts after $40 \mathrm{~h}$ of incubation at $22^{\circ} \mathrm{C}$ (Table 2) showed a significant difference in amoebae yield between $E$. coli в (lon) and $E$. coli $\mathrm{B} / \mathrm{r}(l o n s u l)$ and between two analogous KI 2 mutants $\mathrm{ABI} 899$ (lon) and ABI 157 (lon ${ }^{+}$).

The doubling time for Escherichia coli strain B and $\mathrm{B} / \mathrm{r}$, when incubated on SM agar at $22^{\circ} \mathrm{C}$, was found to be $9 \mathrm{I} \pm 3 \mathrm{~min}$, thus discounting an effect of differences in bacterial growth rate on the yield of slime-mould amoebae. Because of the possibility of filament formation by $E$. coli B cells when incubated at $22^{\circ} \mathrm{C}$, an experiment was designed to test for preferential ingestion, of either of the two strains, as an explanation of the observed differences in slime-mould amoebae yield. Mixed cultures of the two strains, one a leucine- 

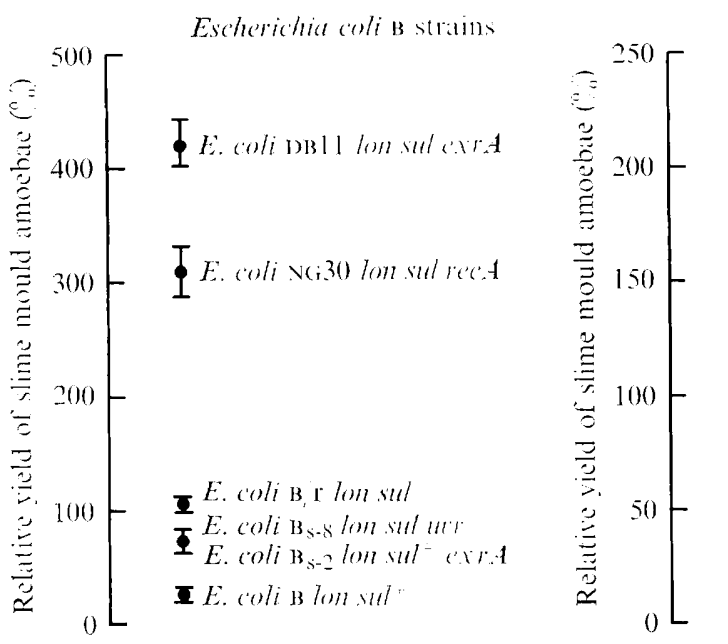

Escherichia coli $\mathrm{k} 12$ strams

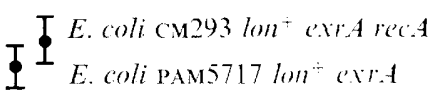

E. coli $\mathrm{AB} 1157$ lon:

耳 E. coli PNM9942 lon exra

ㅍ.coli $\mathrm{AB} 1899 \mathrm{lon}$

Fig. 2. Relative yield of slime-mould amoebae with DNA repair mutants of Escherichia coli. The results are expressed as a percentage of the $E . c o l i \mathrm{~B} / \mathrm{r}$ yield and are the average of counts derived from three plates.

requiring auxotroph, were plated on $\mathrm{SM}$ agar, with and without $10^{6}$ germinated amoebae, and incubated at $22^{\circ} \mathrm{C}$, for $24 \mathrm{~h}$. The bacteria were harvested by washing the plates with $0.067 \mathrm{M}$-phosphate buffer, $\mathrm{pH} 7 \cdot 2$, and plated at suitable dilutions on a defined solid medium lacking leucine, Mr9, allowing growth of the prototroph only, or a complete medium M2O (Forage \& Gillies, 1964) allowing growth of the auxotroph and the prototroph. No difference in the ratio of $E$. coli $\mathrm{\text {B }}$ to $E$. coli $\mathrm{B} / \mathrm{r}$ could be detected between bacteria incubated in the presence or absence of amoebae, indicating that there is no preferential ingestion of either strain by the Dictyostelium discoideum amoebae.

However, the addition of supernatant from an overnight culture of Escherichia coli B to bacteria of an overnight culture of $E$. coli $\mathrm{B} / \mathrm{r}$ significantly reduced the yield of amoebae after $40 \mathrm{~h}$ of incubation (Table 3), indicating the presence of an extracellular factor which influences the slime-mould amoebae growth rate. Since the reverse experiment using supernatant from an $E$. coli $\mathrm{B} / \mathrm{r}$ culture and bacteria from an $E$. coli в culture showed little difference from the $E$. coli в control, it is tentatively proposed that the substance affecting the growth rate of the amoebae is an inhibitor, present in relatively greater quantity in a supernatant of an $E$. coli B than an $E$. coli $\mathrm{B} / \mathrm{r}$ culture.

Interaction with other genes. The DNA repair mutations of Escherichia coli, exrA and $\operatorname{rec} A$ have been shown to suppress lon-induced filament formation after irradiation (Donch, Green \& Greenberg, 1968; Green, Greenberg \& Donch, 1969). Such mutants were used as food source for the amoebae to determine any effect on the growth rate and to look for any interaction with the lon effect. The results, as illustrated in Fig. 2, indicate an enhancement of the yield of amoebae when grown on $l o n^{+}$exr A or $l o n^{+}$rec $A$ double mutants of $E$. coli KI 2 strains or on the analogous $E$. coli $\mathrm{B} / \mathrm{r}$ DNA repair mutants. On the other hand, the yield of amoebae grown with $E$. coli $\mathrm{B}_{\mathrm{S}-8}$, a $u v r$ mutant of $E$. coli $\mathrm{B} / \mathrm{r}$, was only about $65 \%$ of that obtained with the parent strain. The exrA mutation in the lon exrA double mutants, such as $E$. coli B $_{\mathrm{S}-2}$ or $E$. coli $\mathrm{PAM} 9942$, had a small but significant effect on the yield of amoebae.

Suppression of lon- genotype effect on the yield of slime-mould amoebae by F-duction of $F^{\prime} l o n^{+}$. The amoebae yields obtained with Escherichia coli в or $E$. coli B $\mathrm{s} \cdot 2_{2}$ could be modified 


\section{Table 4. Modification of amoebae yields by F-duction of lon $^{+}$}

The amoebae yields are expressed as a percentage of the Escherichia coli $\mathrm{B} / \mathrm{r}$ yield, and are the average of counts derived from three plates.

\begin{tabular}{|c|c|c|}
\hline \multirow[b]{2}{*}{ Strain } & \multicolumn{2}{|c|}{$\begin{array}{c}\text { Amoebae yield }(\%) \\
\text { Escherichia coli } \mathrm{B} / \mathrm{r}=100\end{array}$} \\
\hline & $\begin{array}{l}\text { Parent } \\
\text { strain }\end{array}$ & $\begin{array}{c}\mathrm{F}^{\prime} \text { lon }^{+} \\
\text {conjugant }\end{array}$ \\
\hline Escherichia coli в leu & $22 \pm 3$ & $40 \pm 3$ \\
\hline E. coli $\mathrm{B}_{\mathrm{B}-\mathrm{z}}$ & $38 \pm 4$ & $\mathrm{I} 68 \pm \mathrm{I} 2$ \\
\hline E. coli $\mathrm{B} / \mathrm{r}$ & 100 & $\longrightarrow$ \\
\hline E. coli $\mathrm{DB} I \mathrm{I}$ & $427 \pm 26$ & 一 \\
\hline
\end{tabular}

by F-duction of the $l o n^{+}$gene by conjugation with the $\mathrm{F}^{\prime} l o n^{+}$donor E. coli w3747 (Table 4). The resulting changes were more dramatic with the $E$. coli Bs-2 $_{\text {s. }}$ mutant where the yield of amoebae was increased by approximately a factor of four, although still being only some $50 \%$ of the value obtained with the exrA mutant of $E$. coli $\mathrm{B} / \mathrm{r} E$. coli DBII. A proper control for this experiment is, however, lacking due to our inability to obtain an $E$. coli $\mathrm{B} / \mathrm{r} / \mathrm{F}^{\prime}$ $l o n^{+}$strain and to determine its amoebae yield capacity.

\section{DISCUSSION}

Our experiments rule out differences in bacterial growth rate, spore germination frequency or preferential ingestion of bacteria, as an explanation of the observed differences in Dictyostelium discoideum amoebae growth rate. The variation in growth rate of amoebae, reflected as a difference in final amoebae yield after $40 \mathrm{~h}$ of incubation, is thought to be due to the release of an inhibitor of slime-mould amoebae growth by lon strains. Since the growth curves in Fig. I are approximately parallel and there is no difference in $D$. discoideum spore germination frequency under our experimental conditions it must be concluded that the effect on amoebae growth occurs early in the incubation period when the bacterial number, having reached maximum stationary phase, is at a peak and therefore release of inhibitor is also comparatively high. The diphasic nature of the amoebae growth curves is attributable to the interaction between the growth rate of the amoebae and the consequent replenishment of bacterial number; the plateau in the growth rate of amoebae corresponding to a large reduction in bacterial number (P. A. Farnsworth, unpublished).

That the release of inhibitor of slime-mould amoebae growth rate is due to the lon $^{-}$ phenotype is confirmed by the use of the genetically marked Escherichia coli K 2 strains and by the observation that the F-duction of the lon ${ }^{+}$gene into two lon strains partially reverses the lon $^{-}$effect on the yield of slime-mould amoebae.

The effect of the DNA repair mutants on the yield of amoebae cannot be explained, but the reported interaction between exrA and $\operatorname{rec} A$ mutations and lon-induced filament formation (Donch et al. 1968; Green et al. 1969) perhaps indicates a similar interaction between these genes in respect of capacity to support the growth of slime-mould amoebae.

Hill \& Feiner (I963) found marked differences in the resistance of a number of strains of Escherichia coli to killing by the antibacterial agent crystal violet. They did not offer an explanation for these results, but when compared with our data on the growth of Dictyostelium discoideum amoebae there does appear to be a correlation between resistance to killing by crystal violet, capacity to support the growth of slime mould amoebae and the lon genotype of E. coli strains. 
The unsuppressed lon genotype could bring about such apparently diverse effects in several ways, e.g. as an effect on the cellular permeability barrier (Silver, 1965; Yura \& Wada, I968; Normark, I970; Normark \& Westling, 197I), or as a defect in the cell membrane (Inouye \& Guthrie, 1969; Inouye \& Pardee, 1970; Inouye, 197I).

This work was supported by both the Science Research Council (P. A. F.) and the Medical Research Council (R. J.). We are grateful to Dr M. H. L. Green, M.R.C. Cell Mutation Unit, University of Sussex, for supplying many of the bacterial strains, and to Dr. N. E. Gillies for constructive criticisms of the manuscript.

\section{REFERENCES}

Adler, H. I. \& Hardigree, A. A. (I964). Analysis of a gene controlling cell division and sensitivity to radiation in E. coli. Journal of Bacteriology 87, 720-726.

Brown, D. \& Gillies, N. E. (I972). The relationship between filaments, killing and restoration in irradiated Escherichia coli strain B. Journal of General Microbiology 7o, 46I-470.

Donch, J., Chung, Y. S. \& Greenberg, J. ( 1969 ). Locus for radiation resistance in E. coli B/r. Genetics 6r, 363-370.

Donch, J., Chung, Y. S., Green, M. H. L., Greenberg, J. \& Warren, G. (I971). Genetic analysis of sul mutants of Escherichia coli B. Genetical Research 17, I85-193.

Donch, J., Green, M. H. L. \& Greenberg, J. (1968). Interaction of the exr and lon genes in E. coli. Journal of Bacteriology 96, 1704-1 710.

Forage, A. J. \& Gillies, N. E. (1964). Restoration of Escherichia coli strain B after $\gamma$-irradiation. Journal of General Microbiology 37, 33-39.

Green, M. H. L., GreenberG, J. \& Donch, J. (I969). The effect of a recA gene on cell division and capsular polysaccharide production in a lon strain of E. coli. Genetical Research $\mathbf{1 4}$, I 59-I 62.

Hitl, R. F. \& Feiner, R. R. (I963). Further studies of ultraviolet-sensitive mutants of Escherichia coli strain B. Journal of General Microbiology 35, 105-I I4.

Hirota, Y. \& SNEATh, P. H. A. (I96I). F' and F mediated transduction in Escherichia coli K12. Japanese Journal of Genetics $\mathbf{3}^{6}, 307-3 \mathrm{I} 8$.

Hohl, H. R. \& RAPER, K. B. (1964). Control of sorocarp size in the cellular slime mould Dictyostelium discoideum. Developmental Biology 9, I37-153.

Howard-Flanders, P., Simson, E. \& Theriot, L. (ig64). A locus that controls filament formation and sensitivity to radiation in E. coli KI2. Genetics 49, 237-246.

INOUYE, M. (I97I). Pleiotropic effect of the recA gene of Escherichia coli: uncoupling of cell division from DNA replication. Journal of Bacteriology 106, 539-542.

INOUYE, M. \& GUTHRIE, J. P. (I969). A mutation which changes a membrane protein of E. coli. Proceedings of the National Academy of Sciences of the United States of America 64, 957-96r.

INOUYE, M. \& PARDEE, A. B. (1970). Changes of membrane proteins and their relation to DNA synthesis and cell division of Escherichia coli. Journal of Biological Chemistry 245, 5813-5819.

KANtor, G. J. \& DeERING, R. A. (1968). Effect of nalidixic acid and hydroxyurea on division ability of Escherichia coli fil ${ }^{+}$and lon strains. Journal of Bacteriology 95, 520-530.

Konisn, T. J., Barkley, D. S., Chang, Y. Y. \& Bonner, J. T. (I969). Cyclic AMP; a naturally occurring acrasin in the cellular slime moulds. American Naturalist ro2, 225-233.

Normark, S. (1970). Genetics of a chain-forming mutant of Escherichia coli. Transduction and dominance of the envA gene mediating increased penetration to some antibacterial agents. Genetical Research 16, $73-78$.

Normark, S. \& WestLing, B. (I971). Nature of the penetration barrier in Escherichia coli KI2: effect of macromolecular inhibition on penetrability in strains containing the envA gene. Journal of Bacteriology 108, $45-50$.

SILVER, S. (1965). Acriflavine resistance: a bacteriophage mutation affecting the uptake of dye by infected bacterial cells. Proceedings of the National Academy of Sciences of the United States of America 53, 24-30.

Sussman, M. (1964). Biochemical and genetic methods in the study of cellular slime mould development. In Methods in Cell Physiology, vol. 2, p. 397. Edited by D. M. Prescott. New York: Academic Press. 
WALKER, J. R. \& PARDEE, A. B. (1967). Conditional mutations involving septum formation in Escherichia coli. Journal of Bacteriology 93, 107-I I 4.

WALKER, J. R. \& SMITH, J. A. (1970). Cell division of the Escherichia coli lon ${ }^{-}$mutant. Molecular and General Genetics 108, 249-257.

YURA, T. \& WADA, C. (1968). Phenethyl alcohol resistance in E. coli. Genetics 59, 177-190. 